\title{
The Effect of Using Frontloading Strategy in Teaching Reading Comprehension at The Seventh Grade Students of SMP N 10 Bengkulu In The Academic Year of 2018/2019
}

\author{
Nani Windiati \\ English Education Study Program, Department of Language and Art \\ University of Bengkulu \\ naniwindiati15@gmail.com \\ Arasuli \\ English Education Study Program, Department of Language and Art \\ University of Bengkulu \\ arasulimsi@gmail.com \\ Rudi Afriazi \\ English Education Study Program, Department of Language and Art \\ University of Bengkulu \\ rudiafriazi88@gmail.com
}

\begin{abstract}
This study was conducted to find out the effect of using frontloading strategy in teaching reading comprehension at the seventh grade students of SMPN 10 Bengkulu. This research was a quasi experimental research that is one short experiment which used post-test only. The population of this research were the seventh grade students of SMPN 10 Bengkulu there are 180 students. The sample of this research were 57 students from two classes; the experimental class and control class. The experimental class was treated by using frontloading strategy, while the control class was taught by conventional strategy. The two classes have similar ability in English based on the scores of mid-term examination. In experimental class there was a significant positive effect towards the students reading comprehension (it was found that the t-count 2.047 while t-table was 1.676). T-count was bigger than t-table $(2.047<1.676)$. Based on those results, it can be assumed frontloading strategy was effective in increasing students' reading comprehension.
\end{abstract}

\section{Key words: Frontloading Strategy, Reading Comprehension}

\begin{abstract}
ABSTRAK
Penelitian ini dilakukan untuk mengetahui pengaruh penggunaan strategi frontloading dalam pengajaran membaca pemahaman pada siswa kelas tujuh SMPN 10 Bengkulu. Penelitian ini merupakan penelitian eksperimental semu yang merupakan salah satu eksperimen singkat yang
\end{abstract}


hanya menggunakan post-test. Populasi penelitian ini adalah siswa kelas VII SMPN 10 Bengkulu yang berjumlah 180 siswa. Sampel penelitian ini adalah 57 siswa dari dua kelas; kelas eksperimen dan kelas kontrol. Kelas eksperimen diperlakukan dengan menggunakan strategi frontloading, sedangkan kelas kontrol diajarkan oleh strategi konvensional. Kedua kelas memiliki kemampuan yang sama dalam bahasa Inggris berdasarkan nilai ujian tengah semester. Di kelas eksperimen ada efek positif yang signifikan terhadap pemahaman membaca siswa (ditemukan bahwa t-hitung 2,047 sedangkan t-tabel adalah 1,676). T-hitung lebih besar dari t-tabel $(2,047$ $<1,676)$. Berdasarkan hasil tersebut, dapat diasumsikan bahwa strategi frontloading efektif dalam meningkatkan pemahaman membaca siswa.

\section{Kata kunci: Strategi Frontloading, Pemahaman Membaca}

\section{Introduction}

Reading is one of the most important skills that should be mastered and acquired by students. Reading as one of the basic language skills is important to access knowledge of information and to make meaning. Reading is a form of communication, using written language or symbols (text). Clarke and Silberstein (2002) said that Reading provides many useful information, knowledge, experiences, and cultures to the reader by the text. The purpose of teaching reading is to help students to comprehend or to get meaning from written text. Reading is also important in teaching learning process, because every activity in the classroom always has relationship with reading.

According to Grabe and Stoller (2002) "Reading comprehension is the ability of understanding and interpreting information in a text correctly, it makes the readers understand what they read in the text. In other words, reading is not only students activity to read a text and finish the task but also students should be able to understand and comprehend the text that they read about the writers' ideas, the writers' utters' or other information that related to the text. Reading also has positive effect on student vocabulary and knowledge on their spelling and writing. They read English text to increase their vocabulary. It can get better knowledge in information. The readers have a lot of information and they should find many information sources that are written in English.

In teaching and learning, students are expected to get some messages from their reading. Since it is generally learned from secondary level of education to the higher education, the students are expected to read a text as well as possible. But in fact, many students have some problems in reading. They still have low ability in reading they have difficulties in understanding the meaning of the text.

In teaching reading the teachers should be able to make their teaching is interesting, enjoyable, and help the students to comprehend the text easily by using appropriate strategy. Therefore, the teachers should be creative to use effective strategy one of them is Frontloading strategy. 
There is previous study by Ita Purwasih (2014) Conducted research entitled "The effectiveness of using Frontloading strategy in increasing vocabulary mastery at the seventh grade students of SMP N 25 Purworejo in the academic year of 2013/2014". The finding of the research, it shows that there is a difference achievement got by the students in experimental group and in control. In post-test the mean score of experimental group is 81.40 and the mean of control group is 70.46. It can be seen that the mean of experimental group was higher than control group in post-test. It shows that t-table is 1.999 and $t$-value is 6.849. It means that t-value was higher than t-table that is $6.849>1.999$. So, it can be concluded the use frontloading strategy increase vocabulary mastery of the seventh grade students of SMP N 25 Purworejo in academic year 2013/2024 is effective. Those previous studies focused on applying Frontloading strategy in teaching reading comprehension. According to the explanation above, the researcher was conduct a research entitled The Effect of Using Frontloading Strategy in Teaching Reading Comprehension at the Seventh Grade Students of SMPN 10 Bengkulu in the Academic Year of 2018/2019

The Effect of This research had a research question were "How is the effect of using Frontloading Strategy in teaching reading comprehension at the seventh grade students of SMPN 10 Bengkulu in the academic year of $2018 / 2019$.

This research had two hypothesis of the research $\mathrm{H}_{1}$ : There is a positive effect of using frontloading strategy in teaching reading comprehension. $\mathrm{H}_{0}$ : There is no positive effect of using frontloading strategy in teaching reading comprehension.

\section{Method}

The design of this research is Quasi-experimental research. Quasiexperimental is the research design which takes sample from two different classes in the same grades which has similarity (Latief, 2010).

This research used post-test only toward experimental and control class. There was no pre-test given to either class (experimental and control class) in order to control for simple testing effect. Experimental class was the class who was taught by using frontloading strategy in teaching reading comprehension and control class was the class who was not taught using frontloading strategy in teaching reading comprehension.

The population of this research were the seventh grade students of SMPN 10 Bengkulu in the academic year of 2018/2019. Total class of seventh grade were six classes. Each class consisted of around 30 students and total number is 180 students of Junior High School No10 Bengkulu in the academic year of 2018/2019. The subject of this research were class $E$ with the man score 75,40 as a experimental class and class D with the mean score 75,90 as a control class. So, it consisted of 57 students.

There are two research instruments in this research. There are observation and reading comprehension test. Observation was used to observe the class during the teaching learning process. The observation 
was done in order to know the teaching and learning activities, students' enthusiasm, students interaction to others and students' activeness during the teaching and learning process. The researcher used the students' observation checklist in observing the class. Reading comprehension is post-test to measure the student's reading comprehension. Post-test item was given to both of classes experimental class and control class after 4 meetings or in the end of meetings. The post-test item created according to the syllabus, so the researcher only took recount text because it is on the syllabus on K13. The form of the test is multiple choice consist of 20 test item, the test item contains questions about 10 questions about multiple choices, 5 completing sentence and 5 Essay.

Before the test administrate, the test must be examined to know the validity and reability of the instrument. Brown (2010), validity is the extent to examine the result of assessent, whether it is appropriate, meaningful, and useful to the purpose of such assessment. The pupose of validity refers to make sure that the test can examine the objected gol which is to test the capability of reading.

\section{Result and Discussion}

\section{Result}

In this chapter the researcher discusses the research result of this research. The data were collected from 57 students of the seventh grade of SMPN 10 Kota Bengkulu in the academic year of 2018/2019. The objectives of the research were to know whether the effect of using frontloading strategy in teaching reading comprehension on the seventh grades students of SMPN 10 Kota Bengkulu achieved significantly higher score than the students who taught by the conventional strategy that usually used by the teacher. The researcher analyzes the result of the tests which are experimental class and control class.

After the treatments, the post-test was conducted to both of classes. Post-test scores used to know the students ability about reading comprehension after the treatments. The result of the post-test score and mean of the experimental class and control class were presented in the following table:

Table 4.2 Post-test Score and Mean

\begin{tabular}{|l|l|l|l|}
\hline Class & $\Sigma$ Students & Total Score & Mean \\
\hline Experimental class & 28 & 2255 & 80,53 \\
\hline Control class & 29 & 2154 & 71,80 \\
\hline
\end{tabular}

The table shows that the total scores of the post-test are 2255 for experimental class and 2154 for control class. The mean of post-test scores of the experimental class 80.53 and the control class 71.80 the difference was 8.73 . 
From the result of post-test scores, we can see that the mean score in the experimental class is higher than control class. This can be influenced by several factors. For example, the strategy that teacher used and the materials that used in teaching learning in the classroom. However, there was difference between experimental class and control class. It means that the strategy that used in experimental class can achieved higher score.

\section{Discussion}

Based on the result of the research, it was found that the significant difference in scores of experimental class which used frontloading strategy with the control class which did not used frontloading strategy. It can be seen by analyzing the data from the differences between two scores of post-test in Experimental class 80.53 and the Control class is 71.80 the difference is 8.73 which had been after given the treatment. By analyzing t-test value formula it was obtained that $t$-value is 2.047. It was higher than significance level of $5 \%$ ( $t$ table $0.05=1.676$ ) with freedom area 55 . The position of $t$-value $=2.047>1.676$. So, the students who are taught by frontloading strategy achieve higher score compare the students who are taught by conventional strategy that usually used by teacher.

The explanation above concludes that frontloading strategy is one of the effective strategy to be taught in reading comprehension on junior high school students. By using frontloading strategy it helped the students to think before reading content or we called as activated their background knowledge. The reading strategies were employed during the study so that the students can improved their comprehension. The reading strategies which were used are activating students "background knowledge; pre-teaching; using predictive skills; sequencing text; cooperative learning; asking and generating question; and story structure analysis.

Besides reading strategies, characteristic of narrative text also contributed to accomplish this study. Narrative text was discovered to be a context for the students to improve their reading comprehension. The use of frontloading strategy was able to facilitate the students to improved their reading comprehension in terms of enriching their vocabulary; increasing their motivation; encouraging their critical thinking; and accommodating them to practice their language skill.

The implementation of frontloading strategy was so simple. First, the students got story in each treatment but before read the story the researcher asked to the students to write 3 words that they know about this story. Then the researcher asked of the students to read the text. After finished read the story, the students found out the difficult words and looked for the meaning with the words in the context. Then the researcher and the students discussed it together. The students made a list of vocabulary, they wrote it in a piece of paper that researcher gave. Students could discuss with others or the teacher.

The researcher gave an explanation about the appropriate meaning. To make the students understand more about the meaning the 
researcher gave synonyms or antonyms of some words. It had been done in every treatment. Also, it was useful to the students to enrich their vocabulary. That was all about the implementation of story in improving students reading comprehension.

The discussion of the impact of using frontloading strategy in improves students reading comprehension for seventh grade of SMPN 10 Bengkulu. The students knew more about the meaning of words. Actually, in frontloading strategy there is a vocabulary expansion, it is a certain activity to help students expand the vocabulary use. Vocabulary expansion could be found when the researcher gave the antonym or the synonym of a word? Then, the researcher gave the explanation about the synonym or the antonym. For example the antonym of "good" is "bad". So it is useful to improve student vocabulary. Vocabulary expansion of words make the students understood about the meaning of word also added their vocabulary enrichment.

Another impact in using frontloading strategy was that students felt easy in remembering the words. It could be occurred because in narrative text there was a repetition. Some words were written more than once. So, when the students found the words that it was written more than one in some sentences even in other paragraph, unconsciously they would try to remember the words again.

The next discussion is about the factors which influenced the success or failure of using narrative text. Based on the research that has been done, the researcher found about the problem also the factors that determine the success of using frontloading strategy in improving students reading comprehension. The first factor is about student motivation. At the second meeting in the treatment 1, the students did not have a high motivation. They ignored the lesson, it could be seen from their behavior. They did not pay attention to the teacher. Of course, it was be an obstacle in applying the lesson. So the second meeting was not good, the goal was not totally achieved. Then the next meeting the researcher gave a motivation, by telling how important English in the world, and suggested them that English was easy and fun. Finally, the students had a high motivation in following the meetings.

From the explanation above it can be concluded that frontloading strategy is really easy to apply and it is so effective. Using frontloading strategy in improving students reading comprehension gave a positive impact to the students. Actually the factors influenced the success or the failure in improving student comprehension depended on how we handled it. It means that when we faced the problem as an obstacle we should changed it to be the supported factors. There were so many advantages found in teaching frontloading strategy at SMPN 10 Bengkulu city. Firstly, it helped the students learned and acquired new word easily. The students can use their background knowledge. Secondly, it involved friendly competition and keeps students interest. Why we called as a competition, because in this study the researcher gave a reward to the students that more active. Like the researcher explained before, that this strategy served students to learned pronouncing, spelling, antonym and synonym of words automatically. 


\section{Conclusion and Suggestion}

\section{Conclusion}

Based on the analysis above, using frontloading strategy in teaching reading comprehension is more effective that without using frontloading strategy in teaching reading comprehension it can be seen in the result of the research. The data analysis of post-test showed that the students who were taught by using frontloading strategy got significantly higher score than the students who were not taught by using this strategy.

The data from the observation showed that the students were more active and participated in the teaching and learning process. It could be seen from the students rubric significance comparative during teaching and learning process.

The data of test by using t-test calculation, $t$-value is bigger that t-table $(2.047>1.676)$ with significant level 0,05 or $5 \%$. It means that $\mathrm{H}_{1}$ was accepted and $\mathrm{H}_{0}$ was rejected. So, this treatment of this research was successful. Therefore, the research concluded that Frontloading Strategy is applicable to implement in teaching reading for Junior High School Students.

\section{Suggestion}

In this study, the researcher hopes that this thesis will be useful for the researcher itself. The researcher believed that using Frontloading Strategy in teaching was effective to the students reading comprehension. The researcher would like to offer some suggestions:

\section{For English teacher}

English teacher is expected to use Frontloading strategy as an alternative strategy in teaching learning process. To make sure that Frontloading strategy is successfully applied, the English teachers should promote active learning in English teaching learning process so the students will be easy and fun to learn new knowledge.

\section{For the next researcher}

The researcher hopes that the finding of the research will be useful for the other researcher in the future and this research need suggestion and criticism to make it better. 
Pp. 171-179

\section{References}

Alyousef, 2005. Reading is an interactive process between a reader and a text. Jakarta: Dharma Bhakti. Unpublished Thesis.

Arikunto, Suharsini, 2013. Prosedure penelitian: Suatu pendekatam praktik. Jakarta : PTRineksa Cipta.

Clarke and Silberstein, 2001. Teahing reading comprehension to students. New York: Te Guilford Press.

Grabe and Stoller, 2002. The teaching reading knowledge test Course. New York: Cambridge University Press

Grabe, W. 2009. Reading in a second language (moving from theory topractice). New York: Cambridge University Press.

Downs. 2017. Read aloud and shared reading connections to students. New York: Cambridge.

Hornby, 2002. Definition of frontloading : Frontloading is the following reasons to the student best learn new words. New york: Oxford University Press.

Dube J, Baker T and Wilhelm J., 2001. Steps of frontloading : there are 8 steps in teaching frontloading. London: Penguin Longman.

Klingner, Janette K., Sharon Vaughn, and Alison Broadman, 2007. Teaching reading comprehension to students with learning difficulties. New York: The Guidford Press.

Morellion, J, 2007. Collaborative strategies for teaching reading comprehension: maximizing your impact. Chicago: ALA Editions.

Purwasih ita, 2014. The effectiveness of using frontloading strategy in increasing vocabulary mastery. Purworejo. Unpublished Thesis. 
Preszler. J. Et.al 2006. Strategies to build student vocabularies using KWL format teacher. Rapid City.

Writer Information

\begin{tabular}{|l|l|}
\hline Name & Nani Windiati \\
\hline Affiliation & $\begin{array}{l}\text { English Education Study Program, Department of } \\
\text { Language and Art, University of Bengkulu }\end{array}$ \\
\hline Email & naniwindiati15@mail.com \\
\hline Phone Number & +6281539294363 \\
\hline
\end{tabular}

